\title{
Comparative behavioral ecology of the White-Bellied Sea Eagle and Brahminy Kite (Aves: Accipitriformes) in Northwestern Malaysia
}

\author{
Abolghasem Khaleghizadeh $^{1^{*}}$ and Shahrul Anuar ${ }^{2}$ \\ ${ }^{1}$ Agricultural Zoology Research Department, Iranian Research Institute of Plant Protection, Agricultural \\ Research, Education and Extension Organization, Tehran, Iran \\ ${ }^{2}$ School of Biological Sciences, Universiti Sains Malaysia, USM 11800, Pulau Pinang, Malaysia \\ Corresponding author ${ }^{\bowtie}$ : akhaleghizadeh@gmail.com
}

Received: 13 August 2019 Accepted: 26 September 2019 Published online: 30 September 2019

\begin{abstract}
Behavioral events of two raptor species, the White-bellied Sea Eagle, Haliaeetus leucogaster Gmelin, 1788 and Brahminy Kite, Haliastur indus Boddaert, 1783 were studied once every two weeks in two locations in northwestern Malaysia, namely Balik Pulau and Kuala Sepetang, from September 2012 to September 2013. The average total number of behavioral events per hour was 45.9 ( \pm 40.3 SD), 117.0 $( \pm 131.7$ SD), and $285.8( \pm 185.0$ SD) for H. leucogaster at Balik Pulau, and $H$. indus at Balik Pulau and Kuala Sepetang, respectively. The total number of individuals of each species observed was significantly influenced by the time of day and weather $(p<0.05)$. It was observed that the percentage of time spent for perching, flying, hunting and competition was significantly different between these two species and between two locations. The total number of behavioral events among observation dates was no different for the White-bellied Sea Eagle than that of the Brahminy Kite. Overall, the percentage of time that the birds spent perching, flying, hunting, social behavior and competition was different between species. The highest rate of successful predation was $94.6 \%$ for $H$. leucogaster while it was lower for $H$. indus at Balik Pulau (72.8\%). The time of day was an effective factor for determining behaviors of $H$. leucogaster while it was not significant for $H$. indus. The effect of boat numbers and weather on behavior varied between species and locations. The state of the tide and the number of crows present did not have any significant effect on activities of these two species. Results of the comparison of the percentage of occurrence of five types of behavior between adults and juveniles showed that behaviors of perching, hunting and social behavior were different for $H$. leucogaster, behaviors of perching, flying and social interaction for $H$. indus at Balik Pulau and behaviors of perching, flying, hunting and social interaction for $H$. indus at Kuala Sepetang. However, they did not show different behavioral events of involving competition.
\end{abstract}

Key words: Behavior, Brahminy Kite, White-bellied Sea Eagle, Malaysia 


\section{Introduction}

Raptors can be divided into diurnal and nocturnal, and sometimes crepuscular, based on biorhythmic activities (Rodriguez-Estrella, 2000). Comparative behavioral studies of raptors usually compare behaviors of two or three coexisting species (Thiebot et al., 2012), examining behaviors such as perching, flying, predatory and other foraging behaviors, and aggressive competition (Koplin et al., 1980; Buttemer et al., 1986). Coexisting species may be comprised of a diurnal raptor and a nocturnal owl species (Sergio et al., 2003) or two diurnal raptor species (Olsen et al., 2006). Such studies have documented behavioral repertoires and time budgets of these species through reporting changes in behavior in response to time and seasons (Xirouchakis, 2007), weather conditions (Machmer and Ydenberg, 1990; Jiménez and Jaksic, 1991) and tidal states (Watson et al., 1991; Dekker et al., 2011).

Studies of behavior of raptors have involved direct field observations (Xirouchakis, 2007) and radio-tracking (Catry et al., 2011), as well as using caged animals (Scherzinger, 1974). Field observations typically involve either scan sampling or focal sampling (Altmann, 1974). In scan sampling, the simultaneous behavior of multiple individuals may be recorded at specified times, while focal sampling involves continuous observation of a particular individual. Behaviors can be recorded as discrete events (exhibition of a behavior at a point in time or expressed as a frequency per unit time) or as behavioral states (continuation or duration of a behavior of an individual) (Gaibani and Csermely, 2007).

The White-bellied Sea Eagle, Haliaeetus leucogaster Gmelin, 1788 and the Brahminy Kite, Haliastur indus (Boddaert, 1783) are resident raptors with diurnal activities living in the Southeast Asian and Australian regions. The eagle species is significantly larger than the kite species. They inhabit coastal areas and tidal ecosystems (Robson, 2002; Khaleghizadeh and Anuar, 2014a). Generally, H. leucogaster and $H$. indus share similar habitats, but they differentiate to a certain extent, according to microhabitats (Khaleghizadeh and Anuar, 2014b; Khaleghizadeh et al., 2014; Khaleghizadeh and Anuar, 2017). It can be stated that $H$. leucogaster prefers offshore islands covered with dipterocarp forest while $H$. indus prefers mangrove forests (Khaleghizadeh and Anuar, 2014a). Although both species are locally common in Malaysia, information about their behaviors are scanty (Indrayanto, 2011; Masduqi, 2011). This study seeks to address this knowledge-gap.

A habitat can be used for multiple purposes such as daytime perching and nighttime roosting of raptors (Becker, 2002). Evaluations of human-raptor interactions can be assessed through documenting the effects of human disturbance (number of events) on eagle numbers, distribution, feeding behavior, and flushing response. The number of individuals and area of hunting in a habitat differ between raptor species. The response of eagles to resume feeding after any disturbance is different and eagles were more sensitive when foraging compared to other behaviors (Grubb and King, 1991). Eagles were less tolerant of human recreationists when they were feeding on the ground than when perching in trees (Stalmaster and Kaiser, 1997). In Malaysia, H. leucogaster is the emblematic species of the Penang National Park and $H$. indus seems to have its highest population in Matang Mangrove Forest. Human disturbance caused by tourism seems to pose the greatest threat in Penang National Park. Agroforestry and fishing boat traffic are two main disturbances in Matang Mangrove Forest. Here we studied the behavior of $H$. leucogaster and $H$. indus in two of their important habitats in Malaysia.

Objectives of the present research were to examine the behavior of $H$. leucogaster and $H$. indus and their interactions in western Peninsular Malaysia. The current study aimed to document the behavioral repertoires and year-round changes in the prevalence of $H$. 
leucogaster and $H$. indus, as a function of various abiotic factors such as time-of-day, tidal states and weather conditions.

\section{Material and Methods}

\section{Study areas}

Fieldwork was conducted in two areas on the west coast of the Malaysian Peninsula, namely, Penang Island and Matang Mangrove Forest (Fig. 1). Penang Island contains several nests of both $H$. leucogaster and $H$. indus (Masduqi, 2011), and Matang Mangrove Forest holds nests of the Brahminy Kite (Indrayanto, 2011). Therefore, they are visible year-round at these two sites and monitoring behavioral events of these species is possible with sufficient data for different times spanning a whole year.

Two stations, where usually several individuals of $H$. leucogaster and $H$. indus have regularly been seen, were chosen for the behavioral study: a) Kuala Sepetang in Matang Mangrove Forest for H. Indus, and b) Balik Pulau for both H. leucogaster and H. indus.

Kuala Sepetang $\left(4^{\circ} 50^{\prime} 05.52 " N, 100^{\circ} 37^{\prime} 38.00^{\prime \prime E}\right)$ is a village adjacent to the central part of Matang Mangrove Forest (Fig. 2). The village is surrounded by mangrove forests, and the Forestry Office of Matang Mangrove Forest is located adjacent to the village. Large numbers of fishing boats pass through the channels around the village and many individuals of the Brahminy Kite forage in the area.

Kuala Sungai Pinang in Balik Pulau (5²3'31.15"N, 100 $\left.11^{\prime} 34.72 " E\right)$ is adjacent to a village with the same name (Fig. 3). The river Sungai Pinang passes through the village. Several White-bellied Sea Eagles and Brahminy Kites forage around the mouth of the river throughout the year. Fishing boats frequently pass through the river mouth. The northern and southern parts of the village are linked to mangrove forests. This area is located at the southern edge of Penang National Park where there is a second gate to the park.

\section{Field observations}

After finding suitable locations for repeated observations on the behavior of $H$. leucogaster and $H$. indus, behavioral observations were conducted at Kuala Sepetang and Balik Pulau, from September 2012 to September 2013. Birds were observed at both sites twice per month; one in the first half and another in the second half of each month. Behavior was recorded for all adults and juveniles. All individuals of $H$. leucogaster and $H$. indus viewed from a distance of $500 \mathrm{~m}$ with the assistance of an Omicron 10x42 pair of binoculars. On each observation day, behaviors of birds were recorded three times: in the morning after sunrise (08:00-09:00), noon (12:30-13:30) and in the evening before sunset (17:00-18:00).

Following Gaibani and Csermely (2007), all-occurrence (or event) sampling was employed. The instantaneous scan method introduced by Altmann (1974) and later used by Tacha et al. (1985) and Palmer et al. (2001) was employed. Therefore, in the present study, activity of all individuals was sampled at one-minute intervals for a duration of 60 minutes. Overall, 158 hours of observations were made at both sites. Behavioral events seen in the field were categorized as perching (including preening), flying (including searching and soaring), hunting (including diving, failed attack, successful attack, and eating), social (including calling, breeding activities, and scavenging) and competition (inter-specific and intra-specific attacks). The rate of successful attack to total hunting attempts for the purpose of prey capture was also calculated as successful predation rate. At each time of the day, the tidal state (low, 
high, flooding or ebbing), weather conditions (sunny, cloudy, rainy), maximum number of crows within the observation field and the number of boats passed during the 60-minute periods were also recorded.

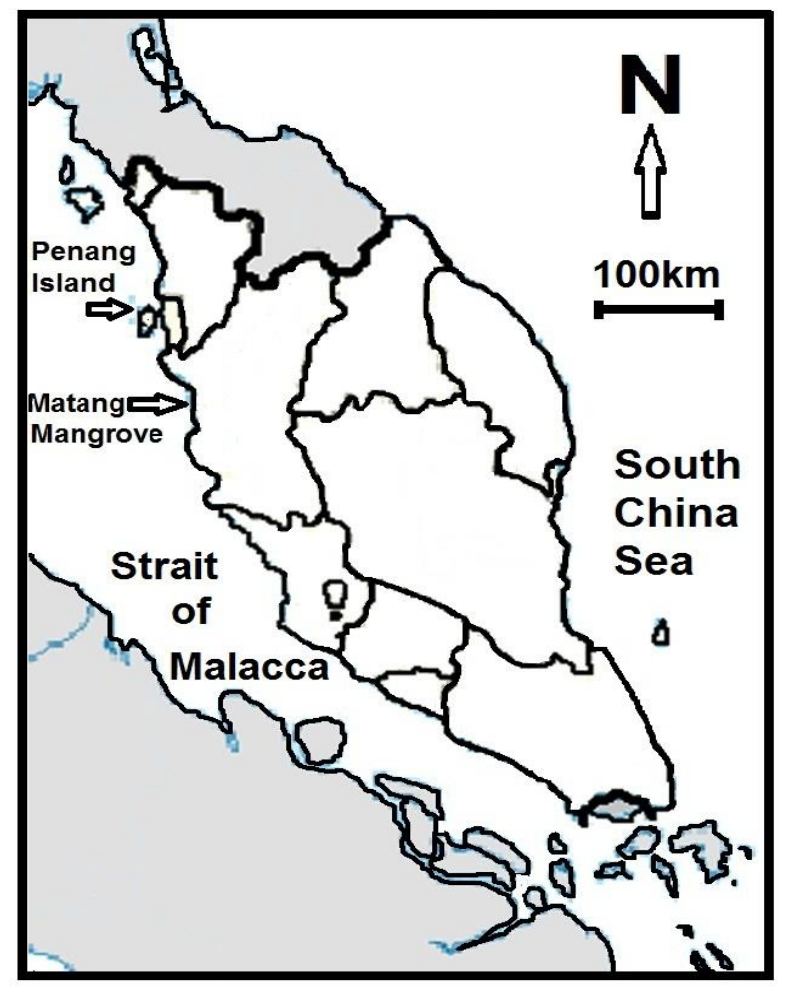

Figure 1: Map of Peninsular Malaysia showing location of Penang Island and Matang Mangrove Forest.

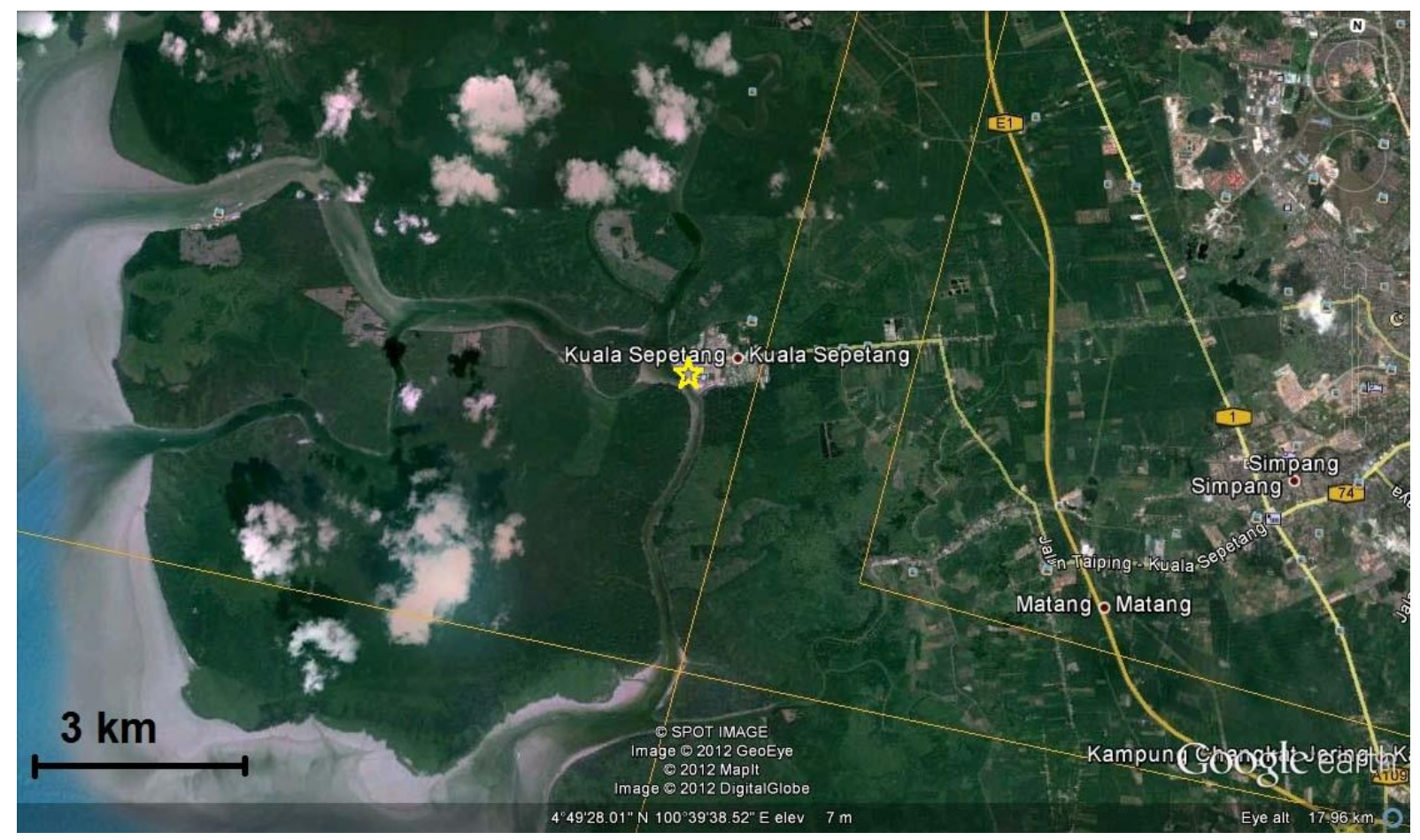

Figure 2: Map of Kuala Sepetang in Matang Mangrove Forest (SPOT 4 imagery). 


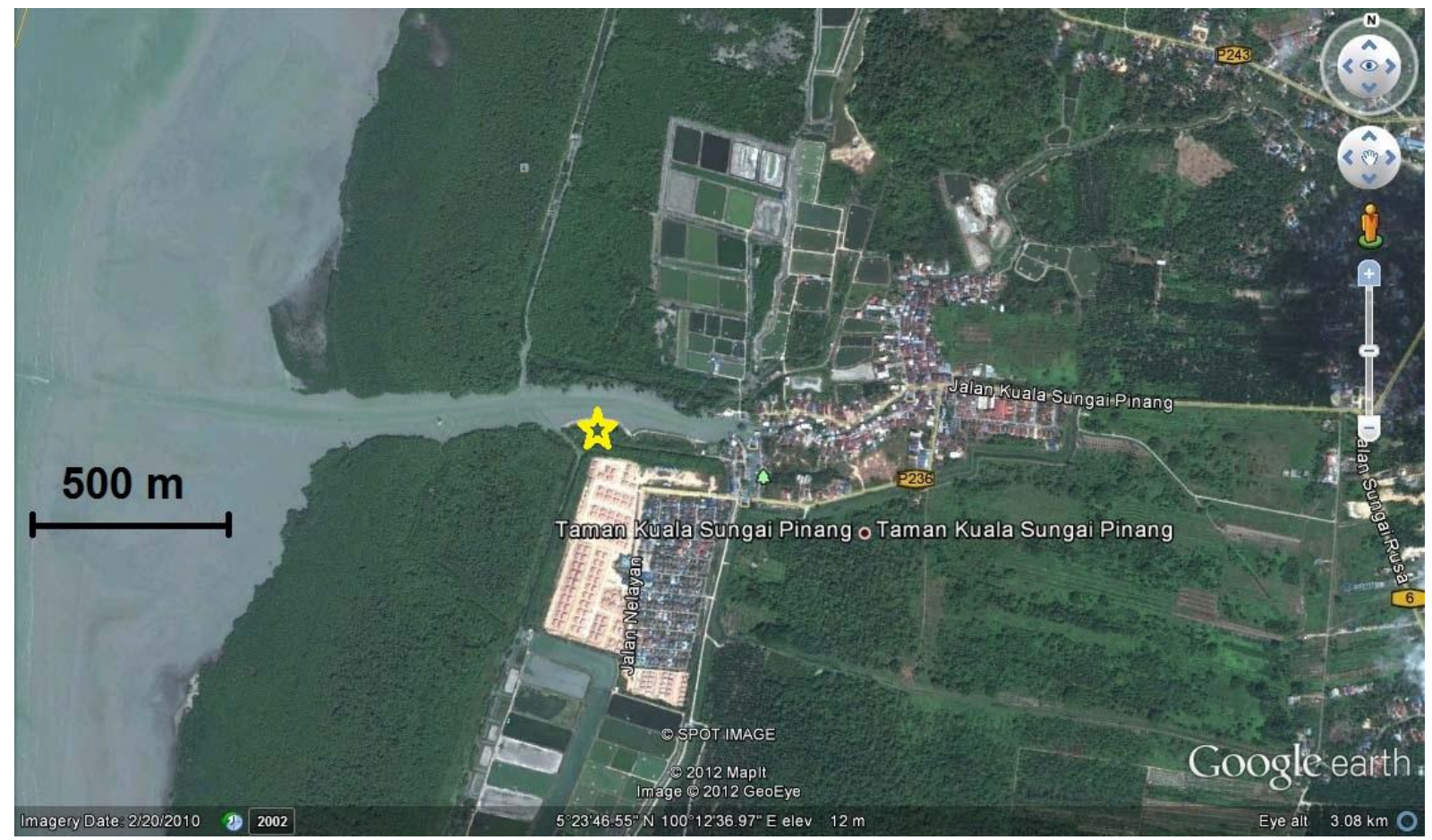

Figure 3: Map of Kuala Sungai Penang in Balik Pulau (SPOT 5 imagery).

\section{Data analysis}

Three sets of data were constructed for 1) H. leucogaster at Balik Pulau, 2) H. indus at Balik Pulau and 3) $H$. indus at Kuala Sepetang. Because H. leucogaster was very rare at the study station at Kuala Sepetang, its data could not be incorporated within the present study analyses. The type of behavior and total number of behavioral events at different times of the year were compared using the one-way ANOVA test. Mean total behavioral events were compared among observation dates using Kruskal-Wallis test. The percentage of the five types of abovementioned behaviors was first transformed to square root (Parsad, 2005). Then five types of behavior of adults and juveniles were compared using two independent non-parametric (Mann-Whitney U) tests while the three data sets of successful attacks for prey catching was compared using a Kruskal-Wallis non-parametric test. The effect of the predictor variables (time of day, tidal state, weather condition and number of boats) on total behavior was analyzed using Multiple Regression analysis. Before this, dates with less than ten total behavioral events were excluded from the analyses. Multiple Categorical variables were transformed to Dummy variables. Before running Multiple Regression analysis, predictors were checked for existence of minimum correlation with total number of individuals of each raptor species. Independent variables were checked for possible multicollinearity using Tolerance and Variance Inflation Factor (VIF) values. Normal Probability Plot (P-P) was used to check overall normality of tests. Outliers were checked using Mahalanobis and Cook's values (Meyers et al., 2006). Data were analyzed with SPSS version 20.

\section{Results}

\section{Total behavioral events}

The average of total behavioral events per hour was 45.9 ( \pm 40.3 SD), $117.0( \pm 131.7$ SD), and 285.8 ( \pm 185.0 SD) for H. leucogaster at Balik Pulau, H. indus at Balik Pulau and at Kuala 
Sepetang, respectively (Fig. 4). Based on a Kruskal-Wallis test, total behavioral events were not different among observation dates for H. leucogaster at Balik Pulau $(p>0.05)$ and for $H$. indus at Kuala Sepetang ( $p>0.05)$ but it was significantly different for $H$. indus at Balik Pulau $(p<0.05)$.

The percentage of the five types of behavior is presented in Table 1. A Kruskal-Wallis test showed significant differences among three sets of data (for two species and locations) for all behaviors, i.e. perching, flying, hunting, social, and competition $(p<0.05$, Table 1). In addition, comparison of the five types of behavior between adults and juveniles of these three sets (Tables 2-3) showed that the behavior of perching, hunting and social interaction was different between adults and juveniles of White-bellied Sea Eagle $(p<0.01$, Table 3). Brahminy Kite showed different behaviors of perching, flying and social interaction between adults and juveniles at Balik Pulau $(p<0.01$, Table 3$)$ while this species showed different behaviors of hunting between adults and juveniles at Kuala Sepetang, in addition to significant differences of three previous behaviors $(p<0.05$, Table 3$)$.

The rate of successful predation was significantly different among the three sets of data for species/location (Kruskal-Wallis, $p<0.05$ ). The rate was lowest for $H$. indus at Balik Pulau (72.8\%) while H. leucogaster had the highest rate of $94.6 \%$ (Table 4).

\section{Effect of environmental factors on behavior}

All predictor variables for $H$. leucogaster were entered in the standard model of Multiple Regression (Adjusted $\mathrm{R}$ square $=0.320, \mathrm{~F}_{8,59}=4.948, p<0.001$ ) and the variables measuring noon and evening had a significant effect on the total number of $H$. leucogaster individuals $(p<0.05$, Table 5). All the environmental variables for $H$. indus at Balik Pulau were entered in the standard model of Multiple Regression but their overall effect was not significant (Adjusted $\mathrm{R}$ square $0.059, \mathrm{~F}_{8,59}=1.522, p>0.05$ ). However, among the predictor variables only the variable measuring cloudy weather condition had a significant effect on the total number of individuals of $H$. indus in Balik Pulau ( $p<0.05$, Table 6). Also, all the environmental variables for $H$. indus at Kuala Sepetang were entered into the standard model of Multiple Regression (Adjusted R square $=0.001, p>0.05$ ) and none of the variables had significant effect on the total number of the species in Kuala Sepetang ( $p>0.05$, Table 7).

Compared with the morning, both noon and evening times showed significant effect on the total behavioral events of $H$. leucogaster $(p<0.05)$. For $H$. leucogaster, the mean total number of behavioral events was 74.7, 23.8 and 39.2 in the morning, noon and evening, respectively. Cloudy weather conditions had a significant effect on the total behavioral events of $H$. indus at Balik Pulau $(p<0.05)$. Tidal states did not show any significant effect in the Multiple Regression analysis $(p>0.05)$.

Regarding boat numbers, there was no correlation between this variable and total number of behavioral events of $H$. indus at Kuala Sepetang $(r=0.116, p>0.05)$ nor at Balik Pulau ( $r=-$ $0.008, p>0.05)$; but there was a significant correlation between number of boats and the total number of behavioral events of H. leucogaster $(r=0.298, p<0.05)$.

The crow species occurring at Balik Pulau was the House Crow, Corvus splendens Vieillot, while at Kuala Sepetang it was the Large-billed Crow, Corvus macrorhynchos Wagler. The average maximum number of crows was $1.32 \pm 2.24$ at Balik Pulau and $1.35 \pm 1.65$ at Kuala Sepetang. There was no correlation between the number of crows and the total number of behavioral events of either $H$. indus at Kuala Sepetang $(r=-0.058, p>0.05)$ or at Balik Pulau ( $r=0.041, p>0.05)$, nor H. leucogaster $(r=0.010, p>0.05)$. 


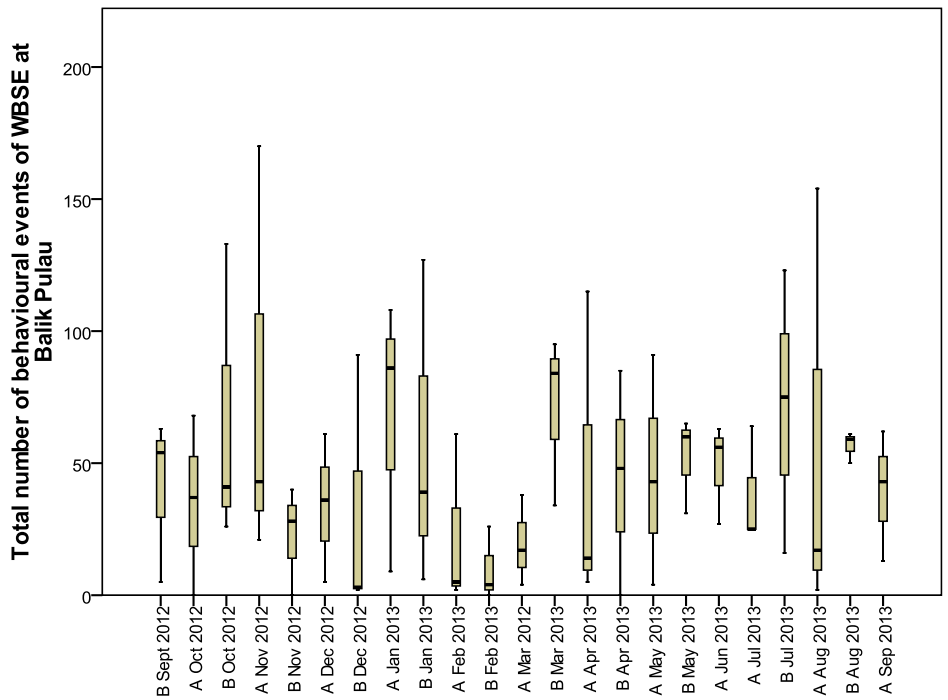

a)
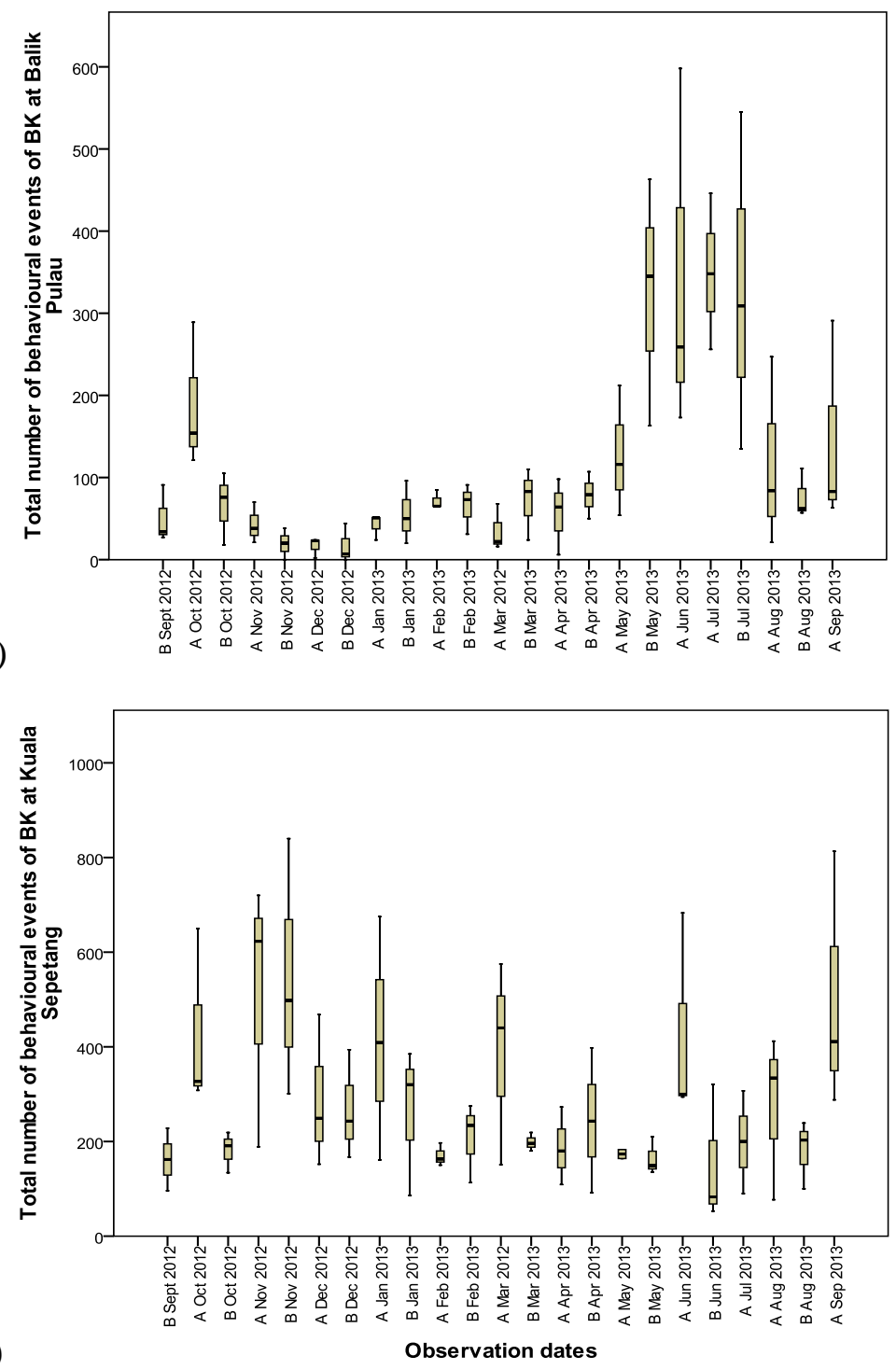

Figure 4: Total behavioral events of a) Haliaeetus leucogaster (WBSE) at Balik Pulau, b) Haliastur indus (BK) at Balik Pulau and c) Haliastur indus (BK) at Kuala Sepetang. 
Table 1: Statistics of percentages of behavior (perching, flying, hunting, social, and competition) of Haliaeetus leucogaster at Balik Pulau, and Haliastur indus at Balik Pulau and Kuala Sepetang.

\begin{tabular}{|c|c|c|c|c|c|c|c|}
\hline \multicolumn{2}{|c|}{ Type of behavior/ Species } & No. & Mean & SD & Min. & Max. & $\begin{array}{c}\text { Kruskal-Wallis test } \\
\text { Asym. Sig. }\end{array}$ \\
\hline \multirow{4}{*}{ Perching } & H. leucogaster & 65 & 6.390 & 3.503 & 0.000 & 10.000 & \multirow{4}{*}{$\mathrm{H}=13.130, \mathrm{P}=0.001$} \\
\hline & H. indus- Balik & 67 & 6.943 & 2.880 & 0.000 & 10.000 & \\
\hline & H. indus- Sepetang & 69 & 5.211 & 2.897 & 0.000 & 9.730 & \\
\hline & Total & 201 & 6.197 & 3.171 & 0.000 & 10.000 & \\
\hline \multirow{4}{*}{ Flying } & H. leucogaster & 65 & 5.088 & 3.302 & 0.000 & 10.000 & \multirow{4}{*}{$\mathrm{H}=21.201 \mathrm{P}=0.001$} \\
\hline & H. indus- Balik & 67 & 5.267 & 2.362 & 0.000 & 100.000 & \\
\hline & H. indus- Sepetang & 69 & 7.187 & 2.307 & 1.710 & 9.930 & \\
\hline & Total & 201 & 5.869 & 2.839 & 0.000 & 10.000 & \\
\hline \multirow{4}{*}{ Hunting } & H. leucogaster & 65 & 1.293 & 2.060 & 0.000 & 7.500 & \multirow{4}{*}{$\mathrm{H}=19.6310 .001$} \\
\hline & H. indus- Balik & 67 & 1.846 & 1.766 & 0.000 & 6.550 & \\
\hline & H. indus- Sepetang & 69 & 2.095 & 1.397 & 0.000 & 8.200 & \\
\hline & Total & 201 & 1.753 & 1.778 & 0.000 & 8.200 & \\
\hline \multirow{4}{*}{ Social } & H. leucogaster & 65 & 1.299 & 1.427 & 0.000 & 5.940 & \multirow{4}{*}{$\mathrm{H}=46.084, \mathrm{P}=0.001$} \\
\hline & H. indus- Balik & 67 & 1.194 & 1.074 & 0.000 & 4.300 & \\
\hline & H. indus- Sepetang & 69 & 0.122 & 0.323 & 0.000 & 1.570 & \\
\hline & Total & 201 & 0.860 & 1.164 & 0.000 & 5.940 & \\
\hline \multirow{4}{*}{ Competition } & H. leucogaster & 68 & 0.334 & 0.902 & 0.000 & 4.710 & \multirow{4}{*}{$\mathrm{H}=26.522, \mathrm{P}=0.001$} \\
\hline & H. indus- Balik & 67 & 0.648 & 0.970 & 0.000 & 3.780 & \\
\hline & H. indus- Sepetang & 69 & 0.869 & 0.701 & 0.000 & 2.190 & \\
\hline & Total & 201 & 0.622 & 0.886 & 0.000 & 4.710 & \\
\hline
\end{tabular}

Table 2: Statistics of five types of behaviors for adults and juveniles.

\begin{tabular}{|c|c|c|c|c|c|c|c|c|c|c|}
\hline \multirow{2}{*}{$\begin{array}{c}\text { Type of } \\
\text { behavior }\end{array}$} & \multirow{2}{*}{$\begin{array}{c}\text { Adult- } \\
\text { Juvenile }\end{array}$} & \multicolumn{3}{|c|}{$\begin{array}{c}\text { White-bellied Sea Eagle } \\
\text { at Balik Pulau } \\
\end{array}$} & \multicolumn{3}{|c|}{$\begin{array}{l}\text { Brahminy Kite } \\
\text { at Balik Pulau }\end{array}$} & \multicolumn{3}{|c|}{$\begin{array}{c}\text { Brahminy Kite } \\
\text { at Kuala Sepetang }\end{array}$} \\
\hline & & $\mathbf{N}$ & $\begin{array}{l}\text { Mean } \\
\text { Rank }\end{array}$ & $\begin{array}{c}\text { Sum of } \\
\text { Ranks }\end{array}$ & $\mathbf{N}$ & $\begin{array}{l}\text { Mean } \\
\text { Rank }\end{array}$ & $\begin{array}{l}\text { Sum of } \\
\text { Ranks }\end{array}$ & $\mathbf{N}$ & $\begin{array}{l}\text { Mean } \\
\text { Rank }\end{array}$ & $\begin{array}{l}\text { Sum of } \\
\text { Ranks }\end{array}$ \\
\hline \multirow{3}{*}{ Perching } & Adults & 23 & 29.170 & 671.000 & 23 & 27.110 & 623.500 & 23 & 32.020 & 736.500 \\
\hline & Juveniles & 23 & 17.830 & 410.000 & 18 & 13.190 & 237.500 & 23 & 14.980 & 344.500 \\
\hline & Total & 46 & & & 41 & & & 46 & & \\
\hline \multirow{3}{*}{ Flying } & Adults & 23 & 21.780 & 501.000 & 23 & 15.200 & 349.500 & 23 & 18.570 & 427.000 \\
\hline & Juveniles & 23 & 25.220 & 580.000 & 18 & 28.420 & 511.500 & 23 & 28.430 & 654.000 \\
\hline & Total & 46 & & & 41 & & & 46 & & \\
\hline \multirow{3}{*}{ Hunting } & Adults & 23 & 28.610 & 658.000 & 23 & 21.280 & 489.500 & 23 & 19.430 & 447.000 \\
\hline & Juveniles & 23 & 18.390 & 423.000 & 18 & 20.640 & 371.500 & 23 & 27.570 & 634.000 \\
\hline & Total & 46 & & & 41 & & & 46 & & \\
\hline \multirow{3}{*}{ Social } & Adults & 23 & 34.430 & 792.000 & 23 & 29.170 & 671.000 & 23 & 27.150 & 624.500 \\
\hline & Juveniles & 23 & 12.570 & 289.000 & 18 & 10.560 & 190.000 & 23 & 19.850 & 456.500 \\
\hline & Total & 46 & & & 41 & & & 46 & & \\
\hline \multirow{3}{*}{ Competition } & Adults & 23 & 24.830 & 571.000 & 23 & 22.430 & 516.000 & 23 & 25.430 & 585.000 \\
\hline & Juveniles & 23 & 22.170 & 510.000 & 18 & 19.170 & 345.000 & 23 & 21.570 & 496.000 \\
\hline & Total & 46 & & & 41 & & & 46 & & \\
\hline
\end{tabular}


Table 3: Statistics of two independent non-parametric test (Mann-Whitney U) for comparison of five types of behaviors between adults and juveniles.

\begin{tabular}{lrrrrr}
\hline \multicolumn{7}{c}{ White-bellied Sea Eagle at Balik Pulau } \\
\hline Variable & Perching & \multicolumn{1}{c}{ Flying } & Hunting & \multicolumn{1}{c}{ Social } & Competition \\
\hline Mann-Whitney U & 134.000 & 225.000 & 147.000 & 13.000 & 234.000 \\
Wilcoxon W & 410.000 & 501.000 & 423.000 & 289.000 & 510.000 \\
Z & -2.893 & -0.870 & -2.890 & -5.906 & -1.072 \\
p-value & 0.004 & 0.384 & 0.004 & 0.000 & 0.284 \\
Mann-Whitney U & Brahminy & Kite at Balik Pulau \\
Wilcoxon W & 66.500 & 73.500 & 200.500 & 19.000 & 174.000 \\
Z & 237.500 & 349.500 & 371.500 & 190.000 & 345.000 \\
p-value & -3.697 & -3.509 & -0.171 & -5.206 & -0.914 \\
& 0.000 & 0.000 & 0.864 & 0.000 & 0.361 \\
Mann-Whitney U & Brahminy Kite at Kuala Sepetang & & \\
Wilcoxon W & 68.500 & 151.000 & 171.000 & 180.500 & 220.000 \\
Z & 344.500 & 427.000 & 447.000 & 456.500 & 496.000 \\
p-value & -4.336 & -2.494 & -2.055 & -2.391 & -0.987 \\
a Grouping Variable: Adult-Juvenile & 0.000 & 0.013 & 0.040 & 0.017 & 0.324 \\
\hline
\end{tabular}

a . Grouping Variable: Adult-Juvenile

Table 4: Statistics of successful predation (\%) of Haliaeetus leucogaster at Balik Pulau, and Haliastur indus at Balik Pulau and Kuala Sepetang.

\begin{tabular}{|c|c|c|c|c|c|c|}
\hline \multirow[t]{2}{*}{ Species/site } & \multirow[t]{2}{*}{ No. } & \multirow[t]{2}{*}{ Mean } & \multirow[t]{2}{*}{ SD } & \multirow[t]{2}{*}{ Min. } & \multirow[t]{2}{*}{ Max. } & $\begin{array}{c}\text { Kruskal- } \\
\text { Wallis test }\end{array}$ \\
\hline & & & & & & Asymp. sig. \\
\hline H. leucogaster at Balik Pulau & 14 & 94.640 & 14.473 & 50.000 & 100.000 & \\
\hline H. indus at Balik Pulau & 21 & 72.810 & 30.430 & 0.000 & 100.000 & \\
\hline H. indus at Kuala Sepetang & 23 & 83.960 & 18.900 & 21.000 & 100.000 & \\
\hline Total & 58 & 82.500 & 24.129 & 0.000 & 100.000 & 0.012 \\
\hline
\end{tabular}

Table 5: Multiple Regression of total behavioral events of Haliaeetus leucogaster with environment variables at Balik Pulau.

\begin{tabular}{|c|c|c|c|c|c|c|c|}
\hline \multirow[t]{2}{*}{ Model } & \multicolumn{2}{|c|}{$\begin{array}{l}\text { Unstandardized } \\
\text { Coefficients }\end{array}$} & \multirow{2}{*}{$\begin{array}{c}\begin{array}{c}\text { Standardized } \\
\text { Coefficients }\end{array} \\
\text { Beta } \\
\end{array}$} & \multirow[t]{2}{*}{$\mathbf{T}$} & \multirow[t]{2}{*}{ Sig. } & \multicolumn{2}{|c|}{$\begin{array}{c}\text { Collinearity } \\
\text { Statistics } \\
\end{array}$} \\
\hline & B & Std. Error & & & & Tolerance & VIF \\
\hline (Constant) & 56.127 & 12.274 & & 4.573 & 0.000 & & \\
\hline Noon & -51.956 & 12.471 & -0.614 & -4.166 & 0.000 & 0.466 & 2.145 \\
\hline Evening & -35.034 & 10.484 & -0.413 & -3.342 & 0.001 & 0.665 & 1.505 \\
\hline Medium tide & 24.680 & 13.149 & 0.217 & 1.877 & 0.065 & 0.757 & 1.321 \\
\hline High tide & 10.548 & 9.850 & 0.127 & 1.071 & 0.289 & 0.724 & 1.382 \\
\hline Cloudy & 17.473 & 9.735 & 0.195 & 1.795 & 0.078 & 0.858 & 1.166 \\
\hline Rainy & 11.380 & 12.159 & 0.100 & 0.936 & 0.353 & 0.885 & 1.130 \\
\hline Boat at Balik & 0.677 & 0.664 & 0.114 & 1.020 & 0.312 & 0.815 & 1.227 \\
\hline Crows at Balik & -1.180 & 2.063 & -0.066 & -0.572 & 0.570 & 0.772 & 1.296 \\
\hline
\end{tabular}

\footnotetext{
${ }^{\mathrm{a}}$. Dependent Variable: Total number of behavioral events of H. leucogaster at Balik Pulau.
} 
Table 6: Multiple Regression of total behavioral events of Haliastur indus with environment variables at Balik Pulau.

\begin{tabular}{|c|c|c|c|c|c|c|c|}
\hline \multirow[t]{2}{*}{ Model } & \multicolumn{2}{|c|}{$\begin{array}{l}\text { Unstandardized } \\
\text { Coefficients }\end{array}$} & $\begin{array}{c}\text { Standardized } \\
\text { Coefficients }\end{array}$ & \multirow[t]{2}{*}{$\mathbf{T}$} & \multirow[t]{2}{*}{ Sig. } & \multicolumn{2}{|c|}{$\begin{array}{c}\text { Collinearity } \\
\text { Statistics }\end{array}$} \\
\hline & B & Std. Error & Beta & & & Tolerance & VIF \\
\hline (Constant) & 147.433 & 47.224 & & 3.122 & 0.003 & & \\
\hline Noon & -41.857 & 47.982 & -0.151 & -0.872 & 0.387 & 0.466 & 2.145 \\
\hline Evening & 51.790 & 40.336 & 0.187 & 1.284 & 0.204 & 0.665 & 1.505 \\
\hline Medium tide & -48.820 & 50.591 & -0.131 & -0.965 & 0.338 & 0.757 & 1.321 \\
\hline High tide & -25.630 & 37.897 & -0.094 & -0.676 & 0.501 & 0.724 & 1.382 \\
\hline Cloudy & -85.037 & 37.455 & -0.291 & -2.270 & 0.027 & 0.858 & 1.166 \\
\hline Rainy & -26.611 & 46.782 & -0.072 & -0.569 & 0.572 & 0.885 & 1.130 \\
\hline Boat at Balik & 1.293 & 2.556 & 0.066 & 0.506 & 0.615 & 0.815 & 1.227 \\
\hline Crows at Balik & -2.094 & 7.936 & -0.036 & -0.264 & 0.793 & 0.772 & 1.296 \\
\hline
\end{tabular}

${ }^{\mathrm{a}}$. Dependent Variable: Total number of behavioral events of H. indus at Balik Pulau

Table 7: Multiple Regression of total behavioral events of Haliastur indus with environment variables at Kuala Sepetang.

\begin{tabular}{|c|c|c|c|c|c|c|c|}
\hline \multirow{2}{*}{ Model } & \multicolumn{2}{|c|}{$\begin{array}{c}\text { Unstandardized } \\
\text { Coefficients }\end{array}$} & \multirow{2}{*}{$\begin{array}{c}\begin{array}{c}\text { Standardized } \\
\text { Coefficients }\end{array} \\
\text { Beta }\end{array}$} & \multirow[t]{2}{*}{$\mathbf{T}$} & \multirow{2}{*}{ Sig. } & \multicolumn{2}{|c|}{$\begin{array}{c}\text { Collinearity } \\
\text { Statistics }\end{array}$} \\
\hline & B & Std. Error & & & & Tolerance & VIF \\
\hline (Constant) & 218.493 & 66.361 & & 3.293 & 0.002 & & \\
\hline Noon & 29.187 & 64.180 & 0.075 & 0.455 & 0.651 & 0.555 & 1.800 \\
\hline Evening & 109.738 & 70.679 & 0.282 & 1.553 & 0.126 & 0.461 & 2.168 \\
\hline Medium tide & -73.158 & 70.014 & -0.140 & -1.045 & 0.300 & 0.842 & 1.187 \\
\hline High tide & -41.683 & 54.407 & -0.109 & -0.766 & 0.447 & 0.748 & 1.337 \\
\hline Cloudy & 37.792 & 50.533 & 0.102 & 0.748 & 0.458 & 0.810 & 1.235 \\
\hline Rainy & 86.451 & 71.934 & 0.178 & 1.202 & 0.234 & 0.688 & 1.453 \\
\hline Boat at Sepetang & 0.586 & 1.861 & 0.052 & 0.315 & 0.754 & 0.554 & 1.805 \\
\hline Crows at Sepetang & -2.857 & 14.707 & -0.026 & -0.194 & 0.847 & 0.879 & 1.137 \\
\hline
\end{tabular}

a . Dependent Variable: Total number of behavioral events of $H$. indus at Kuala Sepetang

\section{Discussion}

The number of $H$. leucogaster individuals among observation dates was not different, because the study site at Balik Pulau has been used as a foraging area of the species with low numbers. The number of individuals for population of $H$. indus at Balik Pulau peaked from mid-May to late July, presumably after the release of juveniles (Indrayanto et al., 2011). The number of individuals of $H$. indus at Balik Pulau was changeable because of many factors such as weather conditions, prey availability, breeding season activities and the release of juveniles.

The study showed that only $H$. leucogaster had significant difference in the total number of behaviors among different times of the day, the highest rate was 74.7 in the morning, 39.2 in the evening and 23.8 at noon, while the total number of behaviors in $H$. indus was not different either in Balik Pulau or in Kuala Sepetang. Many raptors such as the Griffon Vulture, Gyps fulvus (Hablitz) had previously showed difference at various times of the day 
with two peaks in the morning and afternoon (Xirouchakis, 2007). The number of raptors among different daytimes was significant for flying birds but insignificant for perching birds (Applegate et al., 2003).

Perching is a sit-and-wait strategy in raptors (Baladrón et al., 2006). Wintering Eurasian Sparrowhawks, Accipiter nisus (Linnaeus) spent $62 \%$ of their time perching (Cresswell, 1996) while Red-backed Hawks, Geranoaetus polyosoma (Quoy and Gaimard) spent $78.8 \%$ of their time perching (Baladrón et al., 2006). Larger raptors such as the Golden Eagle, Aquila chrysaetos (Linnaeus) spend even more time perching (77.9\%-84.7\%) (Collopy and Edwards, 1989). In the present study, the proportion of perching activity of $H$. leucogaster individuals was significantly higher than $H$. indus at both sites. The higher rate of perching could also be related to higher rate of successful predation in large raptors. In $H$. leucogaster individuals, both the percentage of perching $(63.5 \%)$ and successful predation rate $(94.6 \%)$ were higher than $H$. indus (35.4\%-58.8\% and $72.8 \%-83.9 \%$, respectively).

The rate of successful hunting varies from 33\% to 76\% among raptors (Toland, 1986; Baladrón et al., 2006). In the Common Kestrel, Falco tinnunculus Linnaeus, the rate was different between sexes, $35 \%$ by males and $27 \%$ by females (Kitowski, 2005). Some species such as the Merlin, Falco columbarius Linnaeus, have shown an even lower rate of 5\% (Page and Whitacre, 1975). However, it seems that H. leucogaster has a higher level of successful attack rate $(94.6 \%)$. The Brahminy Kite also had high rates of $72.8 \%$ and $83.9 \%$ but these rates include the scavenging of dead or immobile prey as well; while, hunting attacks of $H$. leucogaster were all on live prey (A. Khaleghizadeh, field observations).

The proportion of flight activities was significantly different between species and locations in this study, because they include soaring and searching or foraging flights. The lesser flight activities of $H$. leucogaster $(24.3 \%$ ) and the higher percentage for $H$. indus at Kuala Sepetang (56.9\%) are probably because $H$. leucogaster is a hunter of fresh/live prey, while $H$. indus is a partial scavenger (Wells, 1999; Robson, 2002). It is also noticeable that individuals of $H$. indus sometimes gather from other parts of Matang Mangrove Forest at Kuala Sepetang at a crossing point of both large rivers and fishing boats. They gather to catch small and dead fish thrown by fishermen. This behavior was part of scavenging behavior of $H$. indus at Kuala Sepetang.

The proportion of competition among $H$. leucogaster individuals $(0.71)$ was nearly half of those of $H$. indus (1.24-1.41) (Table 1). In the present study, although the crow species was different between the two study areas, the number of crows was not an effective factor on the total number of behavioral events. There is still debate on how crows impact negatively on raptors. However, it seems that the amount of mobbing by crows is considerable as demonstrated by the increased mobbing of taxidermic mounts of the Red-tailed Hawk Buteo jamaciensis (Gmelin, 1788) and Bald Eagle Haliaeetus leucocephalus (Linnaeus) rather than Western Ospreys, Pandion haliaetus (Linnaeus) (Marzluff et al., 2015). Crows can also compete with raptors by killing their potential prey, pursuit of raptors carrying prey, and harassment and pirating of prey (Simmons and Barnard, 2011). However, the Carrion Crow, Corvus corone Linnaeus also displayed more attacks on the Northern Goshawk, Accipiter gentilis (Linnaeus) than the Common Buzzard, Buteo buteo (Linnaeus) (Krüger, 2002) and corvids such as the Hooded Crow, Corvus cornix (Linnaeus) have been shown to steal prey from $F$. tinnunculus (Kitowski, 2005). During the present study observations, several individuals of the House Crow also showed mobbing behavior around perched $H$. leucogaster to chase them away.

Tidal states did not show significant effects on the total number of behaviors of $H$. leucogaster and $H$. indus. Foraging Bald Eagles need a water depth less than $4 \mathrm{~m}$ (to catch 
fish prey); and, they were also dependant on tidal flats (Watson et al., 1991). Haliaeetus leucogaster and $H$. indus often use the estuary of Pinang River as a foraging, predation and perching site, and even for nesting in $H$. indus.

In this study, only cloudy weather conditions had a significant effect on the total number of behavior of $H$. indus at Balik Pulau. Inclement weather had a negative effect on the breeding of the American Kestrel, Falco sparverius Linnaeus (Dawson and Bortolotti, 2000) and rain can also halt behavior of raptors (Thiollay, 1991); as observed during these field studies (A. Khaleghizadeh, field observations).

The number of boats was an effective behavior modification factor only for H. leucogaster. The effect was maximized when the number of boats and total behavioral events of $H$. leucogaster individuals were at their highest at times of ebbing and flooding tidal states (14.6, 66.1, respectively). Similarly, boat numbers have previously been reported to have an effect on Osprey, Pandion haliaetus distribution (Peters and Otis, 2005). Furthermore, the flush distance of Haliaeetus leucocephalus to boats was 126-127 m while perching but it was 218$237 \mathrm{~m}$ while feeding (Stalmaster and Kaiser, 1997). Previous studies on eagle behavior and disturbances have resulted in recommendations for protection of habitats of raptors (Richardson and Miller, 1997). Maintaining necessary buffer zones is based on the flushing distance to disturbances (Stalmaster and Kaiser, 1997). In the buffer zones, restrictions on human activities such as boating near eagle foraging areas will be implemented (Stalmaster and Kaiser, 1997; Wood, 1999).

In order to take into account the findings of the present study with respect to appropriate conservation and management measures, studies should also be carried out on the number of tourists, peak time of tourist activities and the number of boats (both tourist boats and fishing boats) moving about in the coastal areas of the Penang National Park. More studies are necessary to find out the relationship between the behavior of $H$. leucogaster and human activities and disturbances. Long-term assessment of behavior should focus on the response of $H$. leucogaster to changes in its immediate habitat and greater environment.

\section{Acknowledgements}

We are thankful for the financial and logistic support provided by the School of Biological Sciences and RU-Research Grant, Universiti Sains Malaysia. Our special thanks go to several drivers of the school, in particular Mr. Kalimuthu Subramanian who helped us in many ways during the field surveys. Finally, we thank Dr. Danielle Sulikowski for primary review and edition of the manuscript. We thank the anonymous reviewers for their careful reading of our manuscript and their valuable comments and suggestions.

\section{References}

Altmann, J. (1974). Observational study of behavior: sampling methods. Behaviour, 49 (3/4): 227-267.

Applegate, R. D., Flock, B. E. and Applegate, D. R. (2003). Effects of time of day on numbers and activity of fall migrant and wintering Red-tailed Hawks in eastern Kansas. Kansas Ornithological Society Bulletin, 54 (3): 37-39.

Baladrón, A. V., Bó, M. S. and Malizia, A. I. (2006). Winter diet and time-activity budgets of the Red-backed hawk (Buteo polyosoma) in the coastal grasslands of Buenos Aires Province, Argentina. Journal of Raptor Research, 40 (1): 65-70. https://doi.org/ 10.3356/0892-1016(2006)40[65:WDATBO]2.0.CO;2 
Becker, J. M. (2002). Response of wintering Bald Eagles to industrial construction in southeastern Washington. Wildlife Society Bulletin, 30 (3): 875-878.

Buttemer, W. A., Hayworth, A. M., Weathers, W. W. and Nagy, K. A. (1986). Time-budget estimates of avian energy expenditure: physiological and meteorological considerations. Physiological Zoology, 59 (2): 131-149.

Catry, I., Dias, M. P., Catry, T., Afanasyev, V., Fox, J., Franco, A. M. A. and Sutherland, W. J. (2011). Individual variation in migratory movements and winter behaviour of Iberian Lesser Kestrels Falco naumanni revealed by geolocators. Ibis, 153 (1): 154-164. https://doi.org/10.1111/j.1474-919X.2010.01073.x

Collopy, M. W. and Edwards, T. C. (1989). Territory size, activity budget, and role of undulating flight in nesting Golden Eagles. Journal of Field Ornithology, 60 (1): 43-51.

Cresswell, W. (1996). Surprise as a winter hunting strategy in sparrowhawks Accipiter nisus, peregrines Falco peregrinus and merlins F. columbarius. Ibis, 138 (4): 684-692. https://doi.org/10.1111/j.1474-919X.1996.tb04770.x

Dawson, R. D. and Bortolotti, G. R. (2000). Reproductive success of American kestrels: the role of prey abundance and weather. The Condor, 102 (4): 814-822. https://doi.org/10.1093/condor/102.4.814

Dekker, D., Dekker, I., Christie, D. and Ydenberg, R. (2011). Do staging semipalmated sandpipers spend the high-tide period in flight over the Ocean to Avoid Falcon Attacks along Shore? Waterbirds, 34 (2): 195-201. https://doi.org/10.1675/063.034.0208

Gaibani, G. and Csermely, D. (2007). Behavioral studies, In: Bird, D. M. and Bildstein, K. L. (Eds.), Raptor Research and Management Techniques. Hancock House, Surrey, British Columbia, Canada. 7: pp. 117-128.

Grubb, T. G. and King, R. M. (1991). Assessing human disturbance of breeding Bald Eagles with classification tree models. The Journal of Wildlife Management, 55 (3): 500-511. https://doi.org/10.2307/3808982

Indrayanto, P. (2011). Distribution and breeding behaviour of Brahminy Kite (Haliastur indus) on Penang Island and Matang mangrove forest reserve, Kuala Sepetang, Perak. MSc. Thesis. School of Biological Sciences, Universiti Sains Malaysia.

Indrayanto, P., Latip, N. S. A. and Mohd Sah, S. A. (2011). Observations on the nesting behaviour of the Brahminy Kite Haliastur indus on Penang Island, Malaysia. Australian Field Ornithology, 28 (1): 38-46.

Jiménez, J. E. and Jaksic, F. M. (1991). Behavioral ecology of Red-backed Hawks in central Chile. The Wilson Bulletin, 103 (1): 132-137.

Khaleghizadeh, A. and Anuar, S. (2014a). Breeding landscape and nest spacing of two coastal raptors (Accipitriformes: White-bellied Sea Eagle Haliaeetus leucogaster and Brahminy Kite Haliastur indus) in Peninsular Malaysia. Italian Journal of Zoology, 81 (3): 431439. https://doi.org/10.1080/11250003.2014.940004

Khaleghizadeh, A. and Anuar, S. (2014b). Nest tree selection by the Brahminy Kite Haliastur indus in a Rhizophora mangrove forest. Tropical Zoology, 27 (2): 40-52. https://doi.org/ 10.1080/03946975.2014.936751

Khaleghizadeh, A., Santangeli, A. and Anuar, S. (2014). Clear-cutting decreases nest occupancy of Brahminy Kite Haliastur indus in a managed mangrove forest of Southeast Asia. Ocean \& Coastal Management, 93: 60-66. https://doi.org/10.1016/j.ocecoaman. 2014.03.015 
Khaleghizadeh, A. and Anuar, S. (2017). Factors affecting nest-site selection of the Whitebellied Sea Eagle Haliaeetus leucogaster (Gmelin, 1788) in coastal rainforests, Peninsular Malaysia. Tropical Ecology, 58 (1): 115-125.

Kitowski, I. (2005). Sex skewed kleptoparasitic exploitation of common kestrel Falco tinnunculus: the role of hunting costs to victims and tactics of kleptoparasites. Folia Zoologica-Praha, 54 (4): 371-378.

Koplin, J. R., Collopy, M. W., Bammann, A. R. and Levenson, H. (1980). Energetics of two wintering raptors. The Auk, 97: 795-806.

Krüger, O. (2002). Interactions between common buzzard Buteo buteo and goshawk Accipiter gentilis: trade- offs revealed by a field experiment. Oikos, 96 (3): 441-452. https://doi.org /10.1034/j.1600-0706.2002.960306.x

Machmer, M. M. and Ydenberg, R. C. (1990). Weather and osprey foraging energetics. Canadian Journal of Zoology, 68 (1): 40-43. https://doi.org/10.1139/z90-007

Marzluff, J. M., DeLap, J. H. and Haycock, K. (2015). Population variation in Mobbing Ospreys (Pandion haliaetus) by American Crows (Corvus brachyrhynchos). The Wilson Journal of Ornithology, 127 (2): 266-270. https://doi.org/10.1676/wils-127-02-266270.1

Masduqi, M. S. (2011). Predicting the habitat selection and distribution of raptors using Geographic Information System technique: A case study with the White-bellied SeaEagle Haliaeetus leucogaster. MSc. Thesis. Pulau Pinang Malaysia, Universiti Sains Malaysia.

Meyers, L. S., Gamst, G. and Guarino, A. J. (2006). Applied Multivariate Research: Design and Interpretation. Thousand Oaks, SAGE Publications, California, USA $722 \mathrm{pp}$.

Olsen, J., Fuentes, E. and Rose, A. B. (2006). Trophic relationships between neighbouring White-bellied Sea-Eagles (Haliaeetus leucogaster) and Wedge-tailed Eagles (Aquila audax) breeding on rivers and dams near Canberra. Ети - Austral Ornithology, 106 (3): 193-201. https://doi.org/10.1071/MU05046

Page, G. and Whitacre, D. F. (1975). Raptor predation on wintering shorebirds. The Condor, 77 (1): 73-83. https://doi.org/10.2307/1366760

Palmer, A. G., Nordmeyer, D. L. and Roby, D. D. (2001). Factors influencing nest attendance and time-activity budgets of Peregrine Falcons in Interior Alaska. Arctic, 54 (2): 105114. https://doi.org/10.14430/arctic769

Parsad, R. (2005). Transformation of data, In: Parsad, R., Srivastava, R. and Gupta, V. K. (Eds.), Des. Anal. Agric. Exp. Indian Agricultural Statistics Research Institute, New Delhi, India. pp. 637-647.

Peters, K. A. and Otis, D. L. (2005). Using the risk-disturbance hypothesis to assess the relative effects of human disturbance and predation risk on foraging American Oystercatchers. The Condor, 107 (3): 716-725. https://doi.org/10.1650/0010-5422(2005) 107[0716:UTRHTA]2.0.CO;2

Richardson, C. T. and Miller, C. K. (1997). Recommendations for protecting raptors from human disturbance: A review. Wildlife Society Bulletin, 25 (3): 634-638.

Robson, C. (2002). A Field Guide to the Birds of South-East Asia. New Holland Publishers, UK. 504 pp.

Rodríguez-Estrella, R. (2000). Breeding success, nest-site characteristics, and diet of Swainson's hawk (Buteo swainsoni) in a stable population in northern México. Canadian Journal of Zoology, 78 (6): 1052-1059. https://doi.org/10.1139/z00-021 
Scherzinger, W. (1974). Ethology and ontogenetic development of caged Snowy Owls (Nyctea scandiaca). Journal of Ornithology, 115 (1): 8-49. [in German]

Sergio, F., Marchesi, L. and Pedrini, P. (2003). Spatial refugia and the coexistence of a diurnal raptor with its intraguild owl predator. Journal of Animal Ecology, 72 (2): 232245. https://doi.org/10.1046/j.1365-2656.2003.00693.x

Simmons, R. and Barnard, P. (2011). Pied pirates: crow threat to raptors? Africa - Birds and Birding, 16 (5): 50-54.

Stalmaster, M. V. and Kaiser, J. L. (1997). Flushing responses of wintering Bald Eagles to military activity. The Journal of Wildlife Management, 61 (4): 1307-1313. https://doi.org /10.2307/3802130

Tacha, T. C., Vohs, P. A. and Iverson, G. C. (1985). A comparison of interval and continuous sampling methods for behavioral observations. Journal of Field Ornithology, 56 (3): 258-264.

Thiebot, J. B., Cherel, Y., Trathan, P. N. and Bost, C. A. (2012). Coexistence of oceanic predators on wintering areas explained by population-scale foraging segregation in space or time. Ecology, 93 (1): 122-130. https://doi.org/10.1890/11-0385.1

Thiollay, J. (1991). Foraging, home range use and social behaviour of a group-living rainforest raptor, the Red-throated Caracara Daptrius americanus. Ibis, 133 (4): 382-393. https://doi.org/10.1111/j.1474-919X.1991.tb04586.x

Toland, B. (1986). Hunting success of some Missouri raptors. The Wilson Bulletin, 98 (1): $116-125$.

Watson, J. W., Garrett, M. G. and Anthony, R. G. (1991). Foraging ecology of Bald Eagles in the Columbia River Estuary. The Journal of Wildlife Management, 55 (3): 492-499. https://doi.org/10.2307/3808981

Wells, D. R. (1999). The birds of the Thai-Malay Peninsula: covering Burma and Thailand south of the eleventh parallel, Peninsular Malaysia and Singapore, Volume One, Nonpasserines. Academic Press, San Diego, CA, 648 pp.

Wood, P. B. (1999). Bald Eagle response to boating activity in Northcentral Florida. Journal of Raptor Research, 33 (2): 97-101.

Xirouchakis, S. M. (2007). Seasonal and daily activity pattern in Griffon Vulture (Gyps fulvus) colonies on the island of Crete (Greece). Ornis Fennica, 84: 39-46. 